International Journal of Social Science and Economic Research

ISSN: 2455-8834

Volume:06, Issue:01 "January 2021"

\title{
THE SURVIVAL OF ECONOMIC MANAGEMENT UNDER DUALISM OF A SINGLE STATE POWER
}

\begin{abstract}
Assistant Professor Dr. Chattawat Shatnataphat ${ }^{1}$ and Professor Dr. Boonthan Dokthaisong ${ }^{2}$
${ }^{1}$ Lecturer of the Faculty of Law and Political Science Northern College, 888 Village No. 2, Nong Bua Tai Subdistrict Mueang Tak District, Tak63000, Thailand

${ }^{2}$ Lecturer of the Faculty of Political Science and Public Administration Mahachulalongkornrajavidyalaya University, No. 79 Moo 1, Phaholyothin Road, Km55, Lam Sai Sub-district, Wang Noi District, Phra Nakhon Si Ayutthaya Province 13170, Thailand
\end{abstract}

DOI: 10.46609/IJSSER.2021.v06i01.021 URL: https://doi.org/10.46609/IJSSER.2021.v06i01.021

\begin{abstract}
The objectives of this research are: 1 ) Study the problem of survival of the Thai economy and the state regime. 2) Study and compare factors of the Thai economy with the state regime. and 3) Find appropriate recommendations to apply to the Thai economy and the state regime for sustainable survival. It is a qualitative research by using the analysis of document data. The researcher has studied and analysis from articles, textbooks, journals, online media and related research. The results of the study showed that: 1 ) Problems of survival of the Thai economy and the state regime Caused by political change that makes the elite realize that The King is a capable person. And make progress in the direction of the country because the monarch must have true royal power. 2) Compare the factors of the Thai economy with the state regime. Important factors contributing to the long-term economic growth of Thailand. The longer the time of democracy, the more positive effects on economic growth. Democratic countries will be richer than those in dictatorship. By about 20 years, democratic states will tax high rates. Then investing more, supporting more aspects and 3) Suggestions appropriate to apply to the Thai economy and the state regime for sustainable survival. The limited monarchy should be separated from the limited government model.
\end{abstract}

Keywords: Economic Management, Single State Power, The Survival

\section{Introduction}

Democratic regime of government with the King as Head of State under the Constitution Constitutional Monarchy means that it is a regime in which the monarch has prerogative powers only as the constitution and the law give to him. In the absence of a constitution or law to present 


\section{International Journal of Social Science and Economic Research}

ISSN: $2455-8834$

Volume:06, Issue:01 "January 2021"

any royal power to the King It means that The King has no prerogative in such a way as constitutional democracy in every constitution of the Kingdom of Thailand is called. "Democratic government with the King as the Head of State" In the democracy with the King as the Head of State, there are currently 22 countries as well, such as Thailand, England, Japan. Andorra, Spain, is a state with a monarchy in both the absolute monarchy in the form of a monarchy and the democratic regime of the monarchy as the head of state. In each continent. (ThonThong Chantarasu. 1998).

Absolute Monarchy is a monarchy as the head of state and the monarch has immense power, that is, not subject to any legal limitations. Above all laws the prerogative of the King is thus immeasurable, having royal power in every way, without limitation. But there will be limitations, it is because the King restricts his own royal power. (Buddhadasa Bhikkhu. 20000 ) . "Tossophitrajadhamma" which is the moral limitation, the good King will maintain but if the king is going to violate the tenet, it does not mean that the action of the king is void. However, in the past perfect absolute monarchy there is no more. But there is still an absolute monarchy in the form of a "Limited Monarchy" or "Monarchy". Unless it is limited by the provisions of the Constitution, such as legislation is the power of the Parliament. The state budget must first be approved by the National Assembly. Judicial proceedings are the jurisdiction of the cases under the law. But executive power is indeed the prerogative of the King, that is, appointing and removing Prime Minister and Ministers. Which the Cabinet is responsible for the King, etc. Rule in this regime is used in 5 countries and one state is Saudi Arabia. Swaziland, Brunei, Oman, Qatar and the Vatican City State. (Maha Hansa Dhammaso. 2012).

Amon Chantarasomboon. (1974). Therefore, it can be seen that the participatory use of sovereignty of the people, or a combination of direct democracy and indirect democracy. "The use of semi-direct sovereignty" to maintain a political share in which people can participate in a framework that can maintain a balance between direct democracy and indirect democracy. And it is tied together with the sovereign ownership of the people. This must take into account the ability to participate in politics and the ability to generate political efficacy of the people Political efficacy, namely the elements of the principle of decentralization and public political decisionmaking or openness. Opportunities for people to participate in important political activities, etc. Therefore, representative democracy is an appropriate form of governing a country today. Direct democracy reinforces or supports the presence of indirect or representative democracy known as "semi-direct democracy or participatory democracy", which blends the concept of sovereignty theory of the people with power. Sovereignty belongs to the nation together. Which can be described as follows: 1. The concept of the theory of sovereignty belongs to the people who accept that Each person owns a portion of that sovereignty. Prescribing the people to have the right to referendum to nominate the law Initiative Process and to remove political office holders 


\section{International Journal of Social Science and Economic Research}

ISSN: $2455-8834$

Volume:06, Issue:01 "January 2021"

from office Recall, but the concept of sovereignty is national, which is inclusive of all people. Therefore, representatives are free of themselves to act on behalf of the nation. And 2. The concept of both theories mentioned above When looking at the public legal philosophy, it can be seen that the two theories have different views on concomitant sovereignty. Because the concept says That nation was one, indivisible. This is different from the idea that each person is the owner of a different sovereignty. The modern state thus accepts these two theories.

Both theories are currently being used together. Therefore, the researcher needs to study the survival of economic management under the duality of state power, the survival problem of the Thai economy through the state regime, to study and compare factors of the Thai economy with the state regime. And find appropriate recommendations to apply to the Thai economy and the state regime for sustainable survival. And tried to pull both ideas together smoothly in many countries where people's democracy is at the heart of trying to extract the strengths and weaknesses of both theories in order to improve the coherence of the regime. People who have the right and voice to rule the country the people's voice is the voice of heaven that the representatives of the people and the rulers of the country have to hear the voice of the people. Citizens are directly involved in the government of the country.

\section{Research Objectives}

1. To study the problems of the survival of the Thai economy with the state regime.

2. To study and compare factors of the Thai economy with the state regime.

3. To find suitable recommendations for applying to the Thai economy and the state regime for sustainable survival.

\section{Method of Research}

This research study the researcher studied relevant documents and research and presented the survival of economic management under dualism of a single state power Problems of survival of the Thai economy and the state regime. Compare the factors of the Thai economy with the government's regime. And find appropriate recommendations to apply to the Thai economy and the state regime for sustainable survival. Important areas of information include documents, textbooks, online media, and related research, relevant departments that can find information such as the National Library, viewable and non- confidential government documents, etc. Processing period: 10 months from March 2020-30 December 2020

\section{Research Tools}

This research study the researcher conducted the study from the data analysis form from the 
International Journal of Social Science and Economic Research

ISSN: 2455-8834

Volume:06, Issue:01 "January 2021"

document. By collecting data, articles, texts, journals, online media, and related research in order for the researchers to modify the information to be consistent according to the environment to get a clear answer and diverse and facts (Shank, G.D. 2002).

\section{Data Analysis}

This research study the researcher analysis the data. By bringing the data collected to be systematic, orderly, meaning to the data Categorize the meaning of the data, analysed and summarize, collect the meaning that has been recorded from the primary document. Secondary documents Public documents Personal documents All document research data is obtained from studies from various media in accordance with the research objectives. For this reason, document selection for analysis is a very important step. Because there are many documents related to the research issue Which details about various criteria, truth, accuracy, credibility Representation And various meanings

\section{Research Framework}

From the concepts and related research, therefore, the conceptual framework of the research is shown in Picture 1.

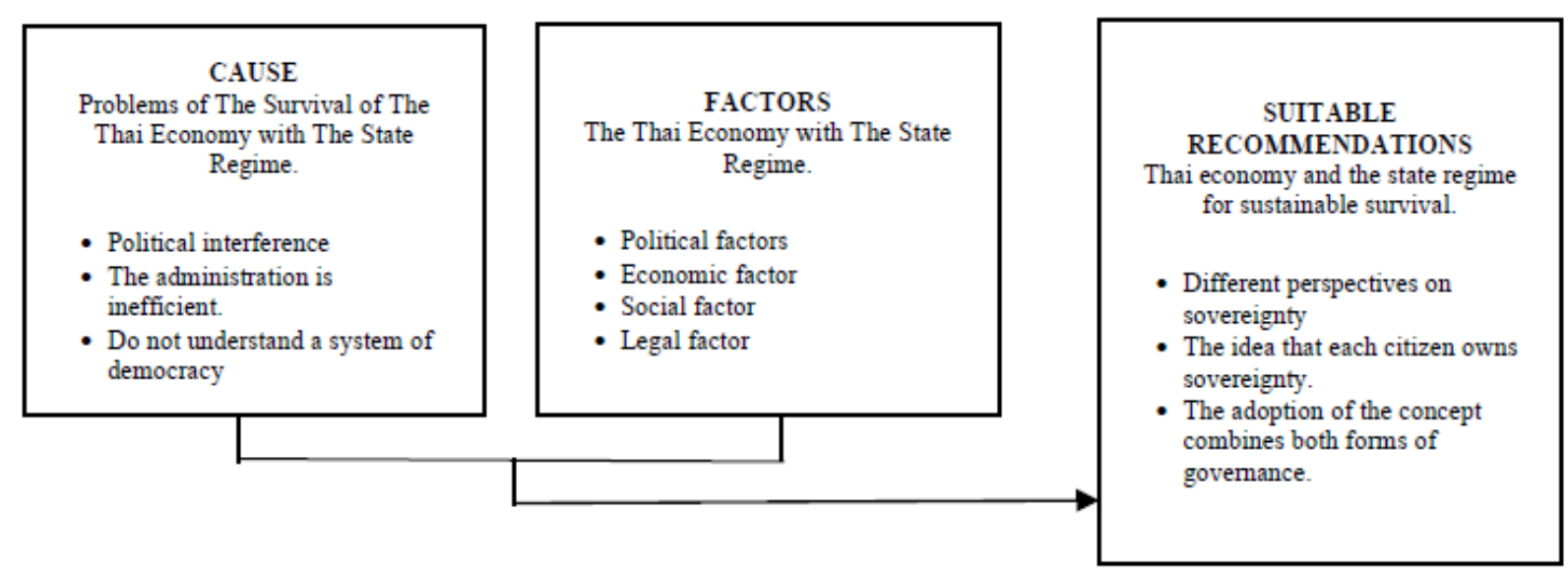

Picture 1 Research conceptual framework

\section{Research Results}

The Survival of Economic Management Under Dualism of a Single State Power The researcher obtained the results of the study according to the objectives as follows: 


\section{International Journal of Social Science and Economic Research}

ISSN: $2455-8834$

Volume:06, Issue:01 "January 2021"

According to the study of objective 1) To study the problems of the survival of the Thai economy with the state regime. Political interference Causes of political interference Foreign and Thai academics Used to analyze the military intervention in politics. It found that the main stimulus for military intervention in politics is corporate interest, which is autonomy and noninterference from other social groups. (exclusiveness) in activities considered by the military to be the primary responsibility For Thai politics the interests of a military group are not the only limited corporate interest. If there are also political interests, such as political positions If the Thai Military Corps is a professional soldier, it will aim to protect the interests of the group and ensure independence, not interfered by other social groups. In activities that are the primary responsibility of the military, there is no political role. The military also needs to be sure that the government gives priority to the military and some of its policies related to military activities. So directly Restricting military roles Therefore often using methods of allowing military representatives in political circles, for example, it is a practice that the Minister of Defense must be appointed by the leadership of the military. Although there has been a relief for the military to play such a political role. But it is not a guarantee that a coup will not happen again, as there are many factors that play a role in determining the extent of military intervention, that the military will be more likely to carry out a coup (Nithi Eowsriwong. 2012. 45-46). The administration is inefficient. The civilian government is inadequate to run the country from the severe political conflict. After the 2006 coup, a political group with many different ideas and ideologies emerged that formed a deep-rooted conflict in Thai society until today. During the period of Ms. Yingluck's government Faced with charges of being a nominee or representative of Lt. Col. Thaksin or Thaksin regime Which had been opposed by the People's Alliance for Democracy before the 2006 coup, protests against the government of Samak and Somchai before disintegrating into a new group. The lack of transparency in the implementation of civilian government policies that may show corruption or conflicts of interest. Throughout her administration under the government, Ms. Yingluck Shinawatra has been positively questioning the implementation of policies that are mistaken and may result in corruption or conflicts of interest, such as allegations in Fraud case, rice pledge scheme This resulted in significant losses and monetary losses. It is also a benefit to solve the group. In addition, some farmers have suffered from selling rice to the government but have not been paid for a long time. The mismanagement of water that led to the 2011 floods, paying compensation and remedies to those affected by powerless political gatherings, was criticized as a reward for the Red Shirts. The issuance of passports to Lt. Col. Thaksin, who was banned from leaving the country by the court. And was issued a warrant for terrorism and other cases contrary to the regulations of the Ministry of Foreign Affairs On issuing passports the transfer of Mr. Thawin Plaisri, secretary- general of the National Security Council, from office to the point that Ms. Yingluck has to vacate the position of Prime Minister. And Do not understand a system of democracy the term "parliamentary dictatorship" is most often referred to as a civilian government, and is also one of 


\section{International Journal of Social Science and Economic Research}

ISSN: $2455-8834$

Volume:06, Issue:01 "January 2021"

the key words used in politics when governments exercise both executive and legislative powers, ignoring opposition from both political parties. Opposition or the public During the government of Ms. Yingluck Despite being a coalition government from many political parties but it must fall into the claim that it is parliamentary dictatorship as well as the government of Lt. Col. Thaksin, which accusations like this stem from the easy use of the legislative power to enact laws. The accusation that legislation is politically beneficial the opposition party could not win the vote in the House of Commons. Even if it is the power of the parliament, such as an attempt to amend the constitution. Pushing the draft of the National Reconciliation Act Until causing chaos in the parliament meeting Efforts to push forward the End Soi Amnesty Act proposed by Pheu Thai Party the House of Representatives received the draft in Agenda 2 and Agenda 3 with 310 votes 00 abstentions 4, while opposition MPs stood up to protest. In addition, the draft Act was accused of being the Laklab Act due to the rapid and continuous consideration of Agenda 2 and Agenda 3 for 19 hours in total. To be considered in the middle of the night This caused the Ms. Yingluck government to be attacked by accusations of parliamentary dictatorship. In the end, the issuance of the Amnesty Act was a major political turning point, causing Ms. Yingluck's government to announce the dissolution of parliament and there was a coup at a later time.

According to the study of objective 2) To study and compare factors of the Thai economy with the state regime. Political factors Enabling or bringing troops into political space Amidst political crises or public protests each time the government often uses government officials, especially the police, to keep the peace of the assembly. But often times, governments have tried to bring soldiers into political areas and act as peacekeepers instead of police. Especially after the coup in 2006 onwards appears clear in the era of the Abhisit government. Using the military to dissolve the Red Shirt rallies in 2009 and 2010, or even in the Ms. Yingluck government. The enactment of the Emergency Decree gave the military the power to maintain peace around the assembly area. Mass communication was also a factor in the military's role in politics, as evidenced by the importance of military leaders. In interviews or requests for opinions related to the political situation at the time, therefore, allowing or bringing the military into the political area like this would result in a decrease in professional military service and become more politically active. This adversely affects the stability of the democratic development process in the future. Economic factor the expansion of the new middle class Over a decade before the 2014 coup, the world has changed dramatically. Especially the economic and technological progress This creates new capital groups in society and continues to expand in other provinces until the promotion or movement of the new middle class. Replaced the old middle class Until it became a class battle the conflict arose from a view of a political future that was radically different between the old and the new middle class that one would like to see the country develop in a more democratic way. With regard to the people's voice as the main and without the process of interference from the outside of the system. Including creating a equitable society While the other party wants to 


\section{International Journal of Social Science and Economic Research}

ISSN: $2455-8834$

Volume:06, Issue:01 "January 2021"

see a future free of corruption, the government must be good, honest. The equality of society was therefore not a big or necessary issue, especially in politics. In addition, the old middle class tried to fight the new middle class. (Lower middle class), most of whom have established liberal ideas Although they had been on the democratic side before, they gradually separated and turned to rely on and supported the military instead. Social factor

Legal factor Democracy is characterized by free competition between different political groups or parties in order to gain the trust of the majority of the people of the country in the establishment of a government to administer the country in accordance with the policy set by that political party. Offer the public to choose between the campaign Governing structure Democracy is government Whose constitution is the highest law Set structure and the relationship between political institutions, governments, jurisdiction, and the origins of various institutions, including the constitution. And the human rights of the people clearly the form of democracy is divided into the monarchy as the United Kingdom, the Netherlands, Belgium, Denmark, Norway, Sweden, Japan, Malaysia, etc., and the president-headed democracy such as France, the Philippines, the United States. The main principles of democracy have an important principle, namely sovereignty or the supreme power to govern a country, or perhaps state power. It is the power that comes from the people and the person who will have the power to rule must be given Consent by most of the people in the country People have the right to delegate administrative power to the people themselves. By voting to elect a group of people who volunteered to be the chief executive of the country in place of the majority of the people in a fixed period and method, for example, fixed every 2 years, 4 years or 5 years, there must be an election of representatives of the majority. The government must respect the fundamental rights and freedoms of people such as property rights, life rights, freedom of speech, writing, expressing opinions, grouping and freedom of assembly, etc. These Except to maintain national security in order to maintain order to protect the public interest to maintain morality for the goodness of the people or to create justice for the society only Everyone has an equal right to all kinds of services that the State provides to them. Dignity or rank does not create privileges or privileges for that person in any way. And the government holds law and fairness as the norm in Govern and to resolve conflicts between peoples in addition, they must not issue laws that result in retrospective penalties. (Keyes, Chales F. 2010).

The merits and limitations of democracy has both advantages and limitations: The merits of democracy Giving the majority of people an opportunity to rule the country with a minority of people having the right to exist and can oppose the rule of the majority. This advantage contributes to good results for the nation as a whole. Because of the decision to do things with the sound department Most of them will have more accuracy and less errors. At the same time, the minority will be a mirror and wait for the negative consequences that must be prevented from 


\section{International Journal of Social Science and Economic Research}

ISSN: $2455-8834$

Volume:06, Issue:01 "January 2021"

happening all the time Allowing people to enjoy equal access to freedom, for example, rich or poor, have the right to form a political party and run for the election of members of the House of Representatives and the President. Which gives people the opportunity to choose good and capable people to take such positions the law is the standard in which the rule of law applies to everyone, whether rich or poor. Whether it is a government official or the public as a result, everyone is equal by law. And suppress conflicts between the government and the people and between People with each other through peaceful means with a court to judge various cases in accordance with the law Which allows people to live together in peace with the law as a framework for the conduct of everyone

The limitations of democracy There are delays in decisions to be made due to considerable consultation and steps, such as time-consuming individual legislation. Since there must be a debate in the council and it takes time for revisions until they become law enforcement. For this reason, leaders of developing countries who have problems that need to be resolved urgently often think that democracies are not a good fit for their country. Cost of governing a lot, such as in the election of members of the House of Representatives. Election of senators or election for president Each time requires a large amount of budget. Developing country leaders often think their countries are too poor to implement democracy. It is not suitable for poor and uneducated countries if most of the people in poor and uneducated countries do not exercise their rights to freedom within the framework of the law. That democracy is not suitable for their country Because most people are not ready to rule in a democracy. (Missingham, Bruce D. 2003).

Dictatorship A single leader or the leadership of an army or a group of political parties has the ultimate power to rule. And be able to fully exercise that power without listening to the majority of the country Maintaining the stability of a leader or a leader is more important than protecting the rights and freedoms of the people. People cannot publicly criticize the actions of leaders. A leader or a leader can remain in power for a lifetime or as long as a group. Members of the military also support the general public, have no right to change leaders through constitutional means, and elections of parliament are held in accordance with the constitution. And the parliament is not as important to the governing process as in democracy, that is, the constitution is just the foundation for the power of a leader or a leader. Election of Councilors The representatives are held to allow the people to vote to elect the only candidate that the leader or the delegation has sent to stand for election. Next As the leader or the leader deems appropriate Advantages and limitations of an authoritarian regime the government can make one decision more quickly. Democratic governments, for example, can enact laws for any purpose One thing Without seeking the approval of the majority of the parliament Some solutions are more effective than democracy, such as directing the suppression of riots. Committing a crime and various terrorism More precisely Without fear that it will exceed the power prescribed by the law 


\section{International Journal of Social Science and Economic Research}

ISSN: $2455-8834$

Volume:06, Issue:01 "January 2021"

Because the courts in the dictatorship are not as independent of the judicial process as in democracy. Causing the general public to not have the opportunity to hold important political positions, namely Make good people capable Non-friends or supporters of the rulers have no opportunity to hold important political positions the vast majority of people who are oppressed and lacked in liberties will not fully support government policies. And may try to resist quietly, or else some people may flee to a foreign country. Especially those who are intellectuals Knowledge and ability in various fields, these people will settle in a foreign country. Causing the nation to lack competent human resources and may lead the nation to its destruction as Hitler brought Germany into World War or General Tojo brought Japan into World War II, which resulted in the two countries having suffered catastrophic destruction as democracies and dictatorships have different advantages and limitations. Thus, making groups of individuals and a number of people in different countries Choose a regime that They thought it was appropriate for their country at that time. And able to help solve the political, economic and social problems in their country in the way they believed quickly, as can be seen that during the end of World War II, some countries have changed their rule from dictatorship-to-dictatorship Democracy such as Germany, Italy, Japan, Portugal and some of Spain It changed from democracy to military dictatorship such as the Union of Myanmar, Nicaragua and Ethiopia, etc.

Democracy and dictatorship Therefore, the good and the bad is more dependent on the "person" than that of the entrenched government, whether by election or in a coup. It aims to do it for the nation. Or for your own benefit the truth is seen together Many Asian countries It grew quickly in a tyrannical era like China and Vietnam today. Or South Korea rose during the time of President Pak Chung Hee Which is full dictator As for Singapore, who said Lee Kuan Yew did not use a dictatorship to build a nation? This is because the rule is in the hand of a good person with absolute power. Can order quickly There were no men to wait for the feet to mold the water. Stare only to steal the benefit Which exists in both the opposition and the government It's a political useless item. This story is not burying the word. "Democracy" or "dictatorship", in the past, behaved no different than their origin, but more dependent on "person". Therefore, the royal speech of His Majesty King Rama IX should be adhered to. Especially is "in that country There are both good and bad people. No one will make everyone a good person at all. Making the country happy and normal Therefore not making everyone a good person but in promoting good people for good people to rule the country and control the bad from the power Not to cause trouble and chaos "

From the study in accordance with objective 3) To find suitable recommendations for applying to the Thai economy and the state regime for sustainable survival. Different perspectives on sovereignty Consideration of the classification of sovereignty, namely legal sovereignty. In other words, legal sovereignty is the supreme power of legislation. Or in other words, it is the highest 


\section{International Journal of Social Science and Economic Research}

ISSN: $2455-8834$

Volume:06, Issue:01 "January 2021"

power within the state. The state has the power to enact legislation to enforce compliance, and such competent bodies as Parliament and the legislation are guaranteed to be in force in British John Austin court. Explain that The British House of Representatives has the legal sovereignty because it is the only body that has the legal power and the law that has passed the council, no other organization can denounce it. Therefore, legal sovereignty is a matter of Congress. Political sovereignty It means that sovereignty by politics is the opinion of the people in voting. Therefore, in a country with democratic government Therefore political sovereignty is considered very important. Because it is an expression of the political sovereignty of the people that is to vote. To elect its representatives to exercise legal sovereignty through the National Assembly and this Representative has formed the Legislature. Which has the duty to enact laws that are generally applicable within the country, and there is one who sees that political sovereignty is above legal sovereignty. This is because political sovereignty. It determines the person who uses the legal sovereignty by the process of the election. Factual sovereignty in the event of a revolution or a coup d'état in the state It can be seen that the governing power of the state will be overlapped, that is, the sovereignty will fall on both the legitimate government, the revolutionary or the other party. And when power contention arises, the de jure government is a user of legal sovereignty. For a group of persons who made a revolution or a coup Tried to establish the power to govern the state in which this party will have factual sovereignty and if the revolutionary group or the coup d'état has established a government The de facto government will be called by the government, and if the corps from the legitimate government takes over the government. Can be victorious Is able to seize a lot of rulership from the legitimate government to be successful, that is, able to maintain peace within the country and the majority of people respect and obey the rulership That gained power through a revolution or coup Including international certification (recognition) to the government of the revolutionary group or the coup. Will make the government, in fact, become a lawful state and will be a government with legal sovereignty instead of sovereignty according to facts, therefore, the nature of the sovereignty can be summarized as follows: 1 . A revolution or a coup took place 2. A revolutionary or the coup is able to overthrow the legal sovereignty and maintain peace within the country 3 . Most of the people of the country respect and obey the new rulership 4. International countries adopt new governments. Deformed sovereignty It is the sovereignty over which a lawful government is used to rule a country. A lawful government is a government formed through a legitimate political process, that is, it is a government appointed by the parliament. Which the people picked up means that it is a government appointed by most of the people of the country and external sovereignty Ie that the independence of a State to exist without control or interference from other states means that the State has the sovereignty to establish its relations with other States, for example, it can enter into agreements. Make a treaty to ratify Including the declaration and the cessation of the war or in conclusion External sovereignty is the independence of that state 


\section{International Journal of Social Science and Economic Research}

ISSN: $2455-8834$

Volume:06, Issue:01 "January 2021"

The idea that each citizen owns sovereignty. Sovereignty is defined as the highest authority used to rule a country. Before the change of rule in 1932, Thailand was under an absolute monarchy. The highest power lies with the King. Hence, this Thai supremacy, known as sovereignty in the Western sense and concept, has always belonged to the King since King Chulalongkorn has gathered the supreme power that is in the custody of the nobles was restored to the center of power with the King, and there was a change in the politics of government from the traditional kingdom to the full-fledged state. Which has a centralized government with centralized power There is a concept of sovereignty. Defining boundaries and converting people to citizenship is regarded as the time of the new monarchy of the country. Therefore, during his reign, he could say that he had known the word sovereignty before the 1932 change, the term Thai sovereignty was in the supreme law of the country on behalf of the Constitution for the first time in the Constitution Act. The Provisional Rule of Siam, 1932, Section 1 states that "the supreme power of that country belongs to the people." The supreme power to govern the country is guaranteed to be owned by the people. However, it is unclear whether the supreme power of the people under the Provisional Constitution of the Land of Siam, B.E. 2475, uses the concept of sovereignty to be of the nation or of the people. And although this constitution uses the term "It belongs to the people" but there is no provision for the people to control the work of members of the House of Representatives. Yes, the idea of sovereignty belongs to the people. This was probably because at that time the controversial issue that sovereignty should be of a nation or of a people is not as important as the fight against absolute monarchy and the dissemination of the idea that sovereignty or supremacy belongs to the people. This is because whether the sovereignty or the supremacy belongs to the people or the nation, it opposes the idea that sovereignty belongs to the King. (Connors, Michael Kelly. 2007).

The adoption of the concept combines both forms of governance. Absolute sovereignty It has the following important characteristics. There is absolute power, that is, it must not be restricted from anything, it is the absolute power. And be abundant in itself Without any power to refute All-round general coverage is to spread to everyone. All groups of people within the state the persistence is to live forever, always with the state, without loss. As long as there is a state and the inability to be divided Because it is the highest power as one Abstract power but can be divided by function (Separation of Power), which Thailand has formulated the use of sovereignty according to the parliamentary system. The organization is separated into 3 organizations: the legislative organization, the administrative organization and the judiciary. Which are related Also known as the "parliamentary system" such as England and Japan, etc. It can be seen from the universal sovereignty of each state or country. There will be three sovereignty bodies: legislative, executive and judiciary. The principle of separation of power (Separation of Power) is the principle of governance. The influential philosopher Montesquieu, described in his letter of intent, describes legislative power - the power of general regulation in states, such as legislation, 


\section{International Journal of Social Science and Economic Research}

ISSN: $2455-8834$

Volume:06, Issue:01 "January 2021"

budgeting and monitoring of government functions. The members of the House of Representatives use executive power as an operating power depending on public law, such as the enforcement of laws or legislation that are less important than the legislature. With the government and the cabinet, be a power user and the judiciary It is the power of action, which depends on civil law, is the power to judge legal proceedings, such as in interpreting the law and the constitution. Montesquieu sees that the best government must be a competent government, each used by a different organization. together When a single person or organization combines legislative and executive powers. Freedom cannot be achieved. And if the jurisdiction is not separated from the legislative or executive power, there will be no more freedom. In separating powers in order to protect and ensure the rights and freedoms of the people. So that no one organization may use only one authority as shown in the 2007 Constitution of the Kingdom of Thailand, the current version is mentioned in Section 1, General Chapter 3, that [5] "Sovereignty belongs to the Thai people. The King as Head of State shall exercise such power through the National Assembly, Council of Ministers and Courts in accordance with the provisions of this Constitution. Performing duties of the National Assembly, Cabinet, Courts, as well as constitutional and state agencies Must be in accordance with the rule of law, so the use of the word "sovereignty Belonging to the Thai people "would affect the thoughts of the general public It shows that the Thai people are more interested in politics and government. In addition, people are now more alert to participate in politics. Because politics is a matter of all Thai people and we will soon see a bright future for Thai politics.

\section{Discussion}

Research Study the Survival of Economic Management Under Dualism of a Single State Power The researcher has studied related research. To see the consistency of other researches as follows

Chanan Chanruang. (2011). Political system of government refers to the patterns of human relations that generate agreements and have the power to force members of society to act today. Politics is about the means of obtaining power in the administration and administration of state affairs and the use of the acquired powers to create welfare for the people, or it can mean that it is an activity involving an individual or a group of people. In order to set guidelines, regulations or policies for people in society to follow and live together happily. The work of government officials is government officials, local employees and state enterprises. According to the law and government policy

Amon Chantasomboon. (2008). Politics, in the sense tied to the political system and or the state, Politics refers to the allocation of things of value or resources. With the power that is recognized to lead to compliance or politics is a matter of having one group of people exerting influence on 


\section{International Journal of Social Science and Economic Research}

ISSN: $2455-8834$

Volume:06, Issue:01 "January 2021"

another. To obtain something of social value Politics, therefore, is an activity and a process that takes place in a political system with the goal of achieving a common interest agreement, that is, the goal of allocation of resources. And things that have common values in society Which is one dimension of human behavior, relationships or institutions involved in controlling Influence The exercise of power and authority within the political system in other words, Politics is about building, building and sharing power within a political system or within a state. Which from this dimension of seeking and sharing power Politics will have a narrow meaning, it is a story that is coupled with government. But the allocation of social value by state or authority and influence No matter what purpose Can be viewed as a matter of domination or having power over others Through its institutions, the state reflects the nature of the state as a human community in an area with certain boundaries. Can use force and violence on the basis of justification. Or is it acceptable.

Kovit Wongsurawat. (2011). Gave the definition of a totalitarian regime Dictatorship is the dominance characterized by the centralization of political power in one person or a group or one party. The said person or group of persons can exercise that power to control the people absolutely. Anyone who opposes a leader or leader will be punished for working hard or imprisoned. The dictatorship can split up into three forms of rule: military dictatorship, fascist dictatorship. And the communist dictator as follows

1. Military dictatorship refers to a dictatorship in which the military leadership is a direct or indirect use of dictatorship. And often use martial law or the constitution established by their own faculty as a means of governing. Generally, the military leadership tends to temporarily rule over the country. While the country is at war or after the abolition of democracy It aims to eliminate some of the threats to the security of the state. In most cases, when the events of the chaos subside

2. Fascist dictatorship refers to a dictatorship in which a leader, backed by businessmen and the military, uses dictatorship to rule a country. The leaders of fascist dictatorship often had the socalled political cults. Fascism It is a leading doctrine and aims to use dictatorship to rule the country permanently. Believing that this regime is suitable for their country and will help their country to progress quickly

3. Communist dictatorship refers to the dictatorship regime at the Communist Party. Only one party was accepted. Or support from various groups of people and the army to be a user of dictatorship to rule the country the leadership of the Communist Party believes that Communist dictatorship is a form of government that suits its country. And will help free the proletariat from being oppressed by the bourgeoisie Including making the country prosperous and strong as compared to other countries faster than other regimes. Communist dictatorship is very different 


\section{International Journal of Social Science and Economic Research}

ISSN: $2455-8834$

Volume:06, Issue:01 "January 2021"

from military dictatorship in one thing, and it is important that the military dictatorship control only the political activities of the people. But the communist dictatorship regime uses dictatorship to control all aspects of the activities and life of the people. Whether it's political Economic and social governance.

Advantages of tyranny the government can take steps to solve the problems that arise internally. Or outside the country as quickly as possible with a competent leader Do not listen to the support voice. Or objection from the public the government can solve the problems of the people. Including dangers in various fields That happened to many people well. Because the state is the operator and causing the population of the country to become more disciplined in society

The limitations of dictatorship May be a mistake from the administration of the nation Because people have no opportunity to express their opinions Objection or objection, so if the executive leadership goes wrong, it will seriously damage the country and people do not have the right to freedom to carry out activities. That is beneficial to yourself and your family Because if violated, you must be guilty and punish and carrying out various activities It is in accordance with the policy of a political party that controls the power of a single country. The public has no power to argue against or to participate in formulating policies the state therefore has to monitor the movement of the opposition. Disagree, including constantly punishing the adversary.

Therefore, can be summarized and discussed the country that uses this dictatorship political system Often the result of the environment Domestic politics Including developing countries, independent countries Often faced with many problems, such as division among leaders. Depression, the state lacks effective political institutions. The bureaucracy is full of allies, a privilege system. Not responsible for the happiness of the people, turbulence will arise when people come together to claim their rights to the dictatorship in an occupied coup. This is mostly in the form of military dictatorship, the reason that military dictatorships are often cited in coups. To seize power to maintain the order of the country, the meaning of democracy is often focused on the participation or voice of the people. When democracy values the people as the owners, sovereignty is exercised through political organizations. For the benefit of the people Therefore is very important to allow people to take part in creating their own society through the process of electing members of the House of Representatives to act on behalf of the government to acknowledge the problem Uphold the principle of equality Freedom and dignity This regime assumes that everyone has equal rights and freedoms, and sovereignty must come from all. By giving political freedom and freedom of speech Write and criticize, believe in dignity Have mutual trust People are reasonable people. Know how to think critically Are willing to compromise, tolerate one another Be athletic and always ready to accept the change It is a society comprised of people who have a democratic way of life. Therefore, known as a valuable society 
International Journal of Social Science and Economic Research

ISSN: 2455-8834

Volume:06, Issue:01 "January 2021"

Is a livable society.

\section{Summary / Suggestions}

From the research, it can be summarized as follows. Problems of the survival of the Thai economy through the civil state regime. The conflict between constitution and authoritarianism Looking back, we can see that some leaders use arbitrary power to rule the country. By adhering to certain constitutional provisions that allow and when there is an enforced constitution and for the benefit of the public, that is but contrary to the authority of some leaders This was the cause of the abolition of the constitution by a group of leaders who seized power by citing impropriety reasons the imperfection of the subject matter was one of the reasons the constitution was frequently abolished. For comparing factors of the Thai economy with the state regime, the lack of "constitutionalism" was one of the reasons for the abolition of the constitution. A group of leaders who are the core in governing the country Who are used to power Some groups are still popular in regulating the traditional administration with an emphasis on monopoly management. Is less decentralized Including the administration that protects the state and their own interests and some groups of people Such power groups do not see the importance. And a strong commitment to constitutional popularity Therefore, when people exercise their constitutional rights more than just right Causing even more confusion and situations the pivotalist groups would see that the cause of the chaos came from the use of the constitution, and even that the constitution was sometimes drafted and adopted by the authoritarian groups, such as the 1971 constitution. And recommendations appropriate to apply to the Thai economy and the state regime for sustainable survival. Politicians must respect and obey the intent of the constitution. As can be seen from the Chom Phon government's preservation Kittikachorn and Mr. Thanin Kraivichien tried to use the interim constitution to become a permanent constitution, resulting in some groups of people dissatisfied with the government and trying to abolish the constitution. Likewise, when some members of the House of Representatives fail to obey the intent of the constitution and try to rely on certain loopholes of the constitution to behave as a disciplinarian. Therefore, not only giving people who do not like the constitutional regime as an excuse In just abolishing the constitution But it also causes those who believe in the constitution to lose their faith in the constitution as well. Abolition of the constitution is a major cause of political attitudes and behavior of individuals rather than by the improper provisions of the constitution itself and that of Mr. Thanin Karai. Wichian tried to use a provisional constitution to become a permanent constitution, causing some people to resent the government and trying to try to abolish it. Likewise, when some members of the House of Representatives fail to obey the intent of the constitution and try to rely on certain loopholes of the constitution to behave as a disciplinarian. Therefore, not only giving people who do not like the constitutional regime as an excuse in just abolishing the constitution but it also causes those who believe in the constitution to lose their 
International Journal of Social Science and Economic Research

ISSN: 2455-8834

Volume:06, Issue:01 "January 2021"

faith in the constitution as well. Abolition of the constitution is primarily caused by political attitudes and behavior of individuals rather than by the improper provisions of the constitution itself.

\section{A suggestion}

1. Should study research on the security of the state and the security of the government. Because the state must always exist but the government can always change. If unable to meet the rational needs of the people

2. Should study social research. Cultivating adherence to racist ideas Using various methods with the use of religion as a tool, such as Brahmanism that has the idea of dividing the caste to dominate. Use mescaline literature and use education to dominate thinking outside the box

3. Should study and research the state economy. The concentration of national income reaches $50 \%$ in Bangkok and the rest is spread across different sectors. The South has the least share. But there is a higher income difference than other regions except Bangkok. Overall, the gap between the poor and the rich in Thailand Ranked at the top and so bad all the time.

\section{Reference}

Amon Chantarasomboon. (1974). The King in Thai Law. 1st edition. Bangkok: Auspicious Publication.

Amon Chantarasomboon. (2008). Administrative Law. Bangkok: Winyuchon.

Buddhadasa Bhikkhu (2006). Tosapitrajatham. Bangkok: Mind health.

Chanan Chanruang. (2011). Democratic government. Bangkok: SE-EDUCATION company.

Connors, Michael Kelly. (2007). Democracy and National Identity in Thailand. Copenhagen: Nordic Institute for Asian Studies.

Keyes, Chales F. (2010). From Peasant to Cosmopolitan Villagers: Refiguring the 'Rural' in Northeastern Thailand Paper prepared for a conference on Revisiting Agrarian Transformation in Southeast Asia. Chiang Mai, Thailand.

Kovit Wongsurawat (2011). Political science. Faculty of Political Science. Bangkok: Graduate School Kasetsart University.

Maha Hansa Dhammaso. (2012). Tenorajidham: 10 indicators for corporate leaders. Bangkok: 
International Journal of Social Science and Economic Research

ISSN: 2455-8834

Volume:06, Issue:01 "January 2021"

Si Sanae Publication.

Missingham, Bruce D. (2003). The Assembly of the Poor in Thailand: From Local Struggle to National Protest Movement. Chiang Mai: Silkworm Books.

Nithi Eowsriwong. (2012). Thai social reform after the election: role of elite and people's politics in the politics of the Thai people after. Thaksin, Wasan Panyakaew (bok.). Chiang Mai: Chiang Mai University.

Shank, G.D. (2002). Qualitative Research: A Personal Skills Approach. Upper Saddle River, New Jersey, Pearson Education.

ThonThong Chantarasu. (1998). The King includes the contents of the people's constitution. Bangkok: Matichon Publishing House 